\title{
The Relationship of Human Activity and Water Quality in Riam Kanan Reservoir, South Kalimantan
}

\author{
Aswin Nur Saputra \\ Geography Education Department \\ Universitas Lambung Mangkurat \\ Banjarmasin, Indonesia \\ aswin.geografi@gmail.com
}

\author{
Muhammad Efendi \\ Geography Education Department \\ Universitas Lambung Mangkurat \\ Banjarmasin, Indonesia \\ mefendi307@yahoo.co.id
}

\begin{abstract}
Riam Kanan reservoir is one of the many water sources utilized by the surrounding community. Utilization of Riam Kanan reservoir by the community is used for daily needs. It increases the water fertility level in Riam Kanan Reservoir. Increased fertility occurs almost evenly throughout the waters of the reservoir. The increase in fertility is more due to agricultural activities of the land dry upstream reservoirs and floating net cage activity spread over reservoir waters. People's behavior and habits in managing the land and waters around the reservoir also affect the condition of reservoir waters. This study aims to determine the extent to which the relationship between the increase of fertility of reservoir waters with community activities around the reservoir.
\end{abstract}

Keywords-Eutrophication, Human activity, Riam Kanan Reservoir

\section{INTRODUCTION}

Increasing of population growth contributes to the surrounding environment. Based on data from [1] for population and population density in The Flow Area Riam Kanan from 2010-2013, most of the upstream regions of Riam Kanan reservoir are increasing every year.

Ref [2] mentions on the waters of the reservoir there are floating net cages (KJA) which reaches 600 units with 1 unit consists of 9 ponds, and the size of 1 pond has an area of $7 \mathrm{~m}$ x $7 \mathrm{~m}$. Agricultural activities are still carried out by residents around the reservoir. Agricultural activities by many residents who use chemical fertilizers in the form of urea fertilizer [3]. The use of chemical fertilizers for agriculture and KJA activities have an impact on the reservoir environment that is increasing the fertility of the reservoir waters due to the increase of nutrient input to the reservoir waters. Parry, 1998 in [4] state surface runoff flowing agricultural land is a medium in the distribution of nutrient content from agricultural land to lakes or reservoirs.

The increasingly fertile water conditions of nitrogen and phosphorus accumulation in certain quantities are a major source of pollution and degradation of water quality (USEPA,
1988 in [4]) and lead to bursts of harmful micro algae or Harmful Algal Blooms (HABs) [5]. The negative impact that has occurred is the mass mortality of millions of fish due to ammonia poisoning [6]. Other hazards that can be caused by HABs to humans such as skin disease, digestion, respiratory tract, can even lead to death if continuously consuming water and fish from HABs polluted waters [7].

\section{RESEARCH AREA}

Riam Kanan Reservoir or Pangeran Mohammad Noor Reservoir is located in District Aranio, Kabupaten Banjar, Provinsi Kalimantan Selatan. This reservoir belongs to the Barito River Basin (Watershed), and watershed Sub Riam Kanan.

The total area of the reservoir is 9,200 ha, and the area of the flow area Riam Kanan is $1200 \mathrm{~km} 2$. This reservoir was built in 1965, the last landfill on the main Dam was done in 1971 and started operating in 1972. Riam Kanan reservoir is for irrigation of 6000 ha of farmland, $30 \mathrm{MW}$ of hydropower, raw drinking water source of Banjar $300 \mathrm{~L} / \mathrm{s}$, flood controllers, fishery floating nets, tourism and others.

\section{A. Demographics}

The total population of each sub-district covering the Sub DAS Riam Kanan is 736,933 [1]. This number is increasing every year. The sub-district covering the Sub DAS Riam Kanan area consists of several districts in South Kalimantan. The increase of population every year also contributes to the increase of nutrient content in the waters of Riam Kanan subbasin, especially in Riam Kanan Reservoir. Information on the number and density of the population in each sub-district can be seen in the table 1 . 
TABLE 1. POPULATION DENSITY AT RIAM KANAN SUB WATERSHED

\begin{tabular}{|l|c|c|c|}
\hline \multicolumn{1}{|c|}{ Kecamatan } & Luas $\mathbf{( k m}^{\mathbf{2}}$ ) & $\begin{array}{c}\text { Jumlah } \\
\text { penduduk }\end{array}$ & $\begin{array}{c}\text { Kepadatan } \\
\text { penduduk per } \mathbf{k m}^{\mathbf{2}}\end{array}$ \\
\hline Banjarmasin Timur & 23,86 & 118.429 & 4.963 \\
\hline Banjarmasin Selatan & 20,18 & 155.505 & 4.063 \\
\hline Kertak Hanyar & 45,83 & 42.237 & 922 \\
\hline Gambut & 129,3 & 38.731 & 300 \\
\hline Sungai Tabuk & 147,3 & 60.455 & 410 \\
\hline Landasan Ulin & 73,47 & 56.746 & 614 \\
\hline Banjarbaru Utara & 371 & 47.214 & 1.932 \\
\hline Cempaka & 146,7 & 31.036 & 212 \\
\hline Martapura & 42,03 & 109.565 & 2.607 \\
\hline Aranio & $1.166,35$ & 8.899 & 8 \\
\hline Astambul & 216,5 & 35.088 & 162 \\
\hline Karang Intan & 215,35 & 33.028 & 153 \\
\hline Jumlah & & 736.933 & \\
\hline
\end{tabular}

\section{B. Cultivation Reservoir}

Community activities in the fisheries sector are intended to meet daily needs as well as for additional income. District Banjar as a region that mostly covers the flow area of Riam Kanan also gives influence to the quality of reservoir waters through the activities of the community in the field of fisheries.

Based on data from Agricultural Extension Community of Agriculture Production Field (2016) as seen in Table recorded there are 951 units KJA (Floating Net Cage) in Aranio District. The average KJA is scattered around the reservoir. Increasing the amount of KJA will also contribute to increase nutrient content in reservoir water.

TABLE 2. DISTRIBUTION AMONT OF FLOATING NET CAGE (KJA)

\begin{tabular}{|c|l|c|c|c|c|}
\hline No & \multicolumn{1}{|c|}{ Kecamatan } & $\begin{array}{c}\text { Tambak } \\
(\mathbf{H a})\end{array}$ & $\begin{array}{c}\text { Kolam } \\
(\mathbf{H a})\end{array}$ & $\begin{array}{c}\text { Keramba } \\
\text { (Unit) }\end{array}$ & $\begin{array}{c}\text { Jaring } \\
\text { Apung (Unit) }\end{array}$ \\
\hline 1 & Aluh-aluh & 10,0 & 1,5 & & \\
\hline 2 & Beruntung Baru & & 2,6 & & \\
\hline 3 & Gambut & & 3,0 & & \\
\hline 4 & Kertak Hanyar & & 4,0 & & \\
\hline 5 & Tatah Makmur & & 1,0 & & \\
\hline 6 & Sungai Tabuk & & 44,9 & 110 & \\
\hline 7 & Martapura & & 210,0 & 41 & \\
\hline 8 & Martapura Timur & & & 98 & \\
\hline 9 & Martapura Barat & & 242,0 & & \\
\hline 10 & Astambul & & 2,0 & 30 & \\
\hline 11 & Karang Intan & & 261,2 & 1.980 & 174 \\
\hline 12 & Aranio & & 2,0 & & 951 \\
\hline 13 & Sungai Pinang & & 5,5 & & \\
\hline 14 & Peramasan & & & & \\
\hline 15 & Pengaron & & 2,0 & & \\
\hline 16 & Sambung & & 0,5 & & \\
\hline 17 & Makmur & & & & \\
\hline 18 & Sataraman & & 2,0 & & \\
\hline 19 & Telaga Bauntung & & & & \\
\hline & Jumlah & 10,0 & 791,7 & 2.259 & 1.125 \\
\hline
\end{tabular}

\section{METHOD}

The method used in this research is a descriptive correlation. This correlation to relate the relationship between the quality of the waters of the Riam Kanan Reservoir with the activity of the people around the reservoir. Associated population activities include agricultural activities, fishery activities, and fecal discharges from residents.
The quality of the reservoir water itself is obtained based on empirical modeling results to obtain distribution of fertility level of reservoir waters. Modeling the fertility level of reservoir waters by utilizing remote sensing imagery and sampling of reservoir water [8]. The basis of the classification in modeling the fertility rate of the reservoir adjusts to the trophic status index of [9].

Samples include chlorophyll-a, phosphate, and water clarity parameters. The number of samples processed in the modeling amounted to 20 points and spread throughout the waters of the reservoir. The samples obtained were then tested by the laboratory to determine the content content of each parameter that has been determined.

\section{RESULT AND DISCUSSION}

Based on the results of modeling done [8] note that the level of [10] divides the amount of content in each parameter in trophic classes. The trophic medium class on the Carlson index is similar to the eutrof class on the OECD index. In the eutrof class the total phosphorus content limit is $35 \mu \mathrm{L}-100 \mu \mathrm{L}$ whereas chlorophyll-a $8 \mu \mathrm{L}-25 \mu \mathrm{L}$, and water clarity $3 \mathrm{~m}$ $1,5 \mathrm{~m}$ water fertility in the right cistern reservoir is in the status of trophic medium. In the trophic medium class according to [9] the level of water fertility is already very high and began to be dominated by blue green algae.

The growth of water plants in this class has been widespread and began to disrupt the aquatic ecosystems. This class is just below grade heavy eutrophic

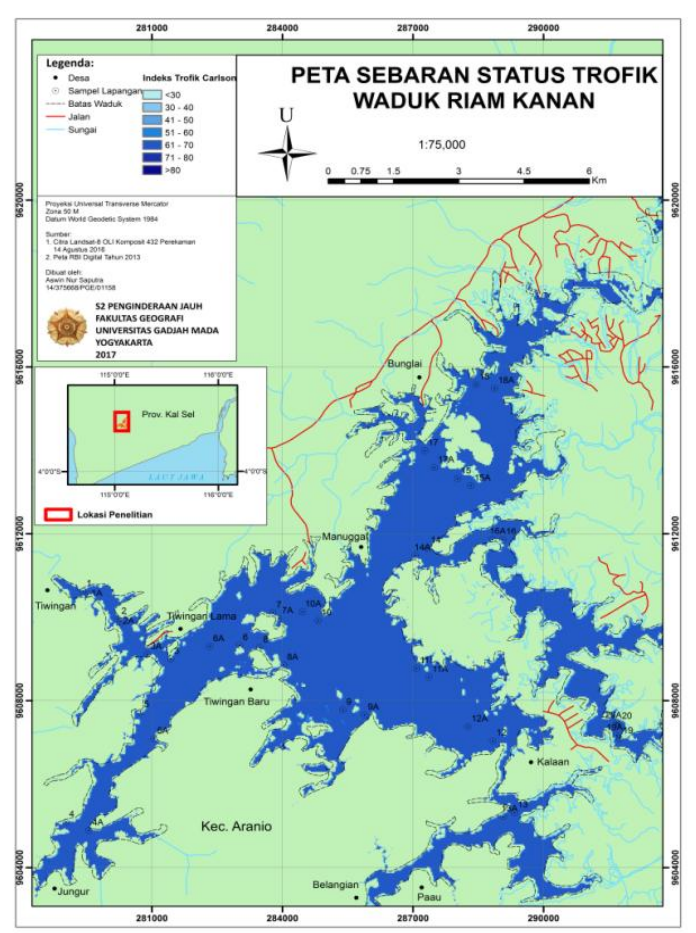

Fig 1. Map Distribution trophic status Riam Kanan Reservoir

Based on the amount of content of each parameter scattered in the waters of the reservoir is known reservoir 
outlet area and reservoir inlet area into areas that have a fairly high fertility rate. The fertility level is seen in the content of chlorophyll a and phosphate which become the determinants of water fertility. The fertility rate is different from the overall water level of reservoir waters based on Carlson trophic index. It is caused the Carlson trophic index already incorporates chlorophyll-a, phosphate, and clarity of water in a single index value divided into several classes so that its index properties become more common.

Outlet reservoirs and inlet reservoirs have several factors that cause high water fertility. The high water fertility in the outlet area of the reservoir due to the accumulation of water discharge from all reservoirs and stuck in the outlet of the reservoir. The relatively quiet current factor also supports increased water fertility in outlet reservoirs.

Increasing the fertility of the waters of the reservoir inlet area, is the accumulation of nutrients from human activities. These activities include agricultural activities and KJA activities scattered in the reservoir inlet area. Nutrient from agricultural activities is obtained through surface runoff which contributes to the remnants of chemical fertilizers used by farmers. While the nutrient contribution of KJA activity is derived from the remnants of fish feed, fish faeces accumulated at the bottom of the reservoir and potentially become a source of ammonia (NH3-) before becoming nitrite (NO2-) [11]. The process of ammonia change into the nitrite involves cyanobacteria in its decomposition (Hill, 2004 in [3]). This process causes the explosion of the micro-algae population in the waters.

Based on the mentioned, it is known that the results of the activities of the residents around the reservoir actually contributed to the condition of reservoir waters. Based on data from [12] the use of fertilizer in Riam Kanan basin in one harvest is Urea N $150 \mathrm{~kg} / \mathrm{ha}$, TSP $75 \mathrm{~kg} / \mathrm{ha}$ and Nitrogen content in Urea $45 \%$ and Phosphate 20\%. So that if it is to be planted with a large area of dryland farming in the area around the reservoir which has an area of 303,811.95 Ha then the total potential content of $\mathrm{N}$ is $20,507,306.6 \mathrm{~kg}$ and the potential amount of $\mathrm{P}$ content is $4,557,179.25 \mathrm{~kg}$. This amount has not been reduced by the amount of content absorbed by soil, plants, and dissolved by surface runoff.

Elements of nutrients that enter the reservoir is the residual fertilizer found on the soil surface which is then dissolved by rain water. While on KJA activity based on the content of nitrogen and phosphorus in fish feed, the amount of feed used every day and feed that is not eaten by the fish, it is estimated that nitrogen and phosphorus is wasted or fall to the bottom of the reservoir derived from fish feed that is $480 \mathrm{~kg} /$ day for Nitrogen and a total of $20 \mathrm{~kg} /$ day for phosphorus. This amount is not included from fish feces [2].

Other residents' activities that contribute to the water fertility rate are the stools that are disposed of daily. Ref [13] in his study stated that in the stool per person contained BOD 35 gr / person / day, total Nitrogen (N) 11.5 gr / person / day and total Phosphate (P) 0.8 gr / person / day. Therefore, based on this matter, it can be assumed from the number of residents of Aranio sub district, the potential of BOD content is $311.4 \mathrm{~kg} /$ day, $\mathrm{N}$ is $102,33 \mathrm{~kg} /$ day, and $\mathrm{P}$ is $7,2 \mathrm{~kg} /$ day.

\section{CONCLUSION}

Based on previous researches, the water reservoir status of Riam Kanan Reservoir continues to increase every year. If it continues to be left then it will also threaten the ecological conditions in the waters of the reservoir. It needs effort from all parties, both government and society in overcoming the problem of increasing the water fertility. This is to keep the Right Riam Reservoir as a potential source of water that is feasible for the people of Banjar and surrounding areas.

\section{REFERENCES}

[1] Badan Pusat Statistik Provinsi Kalimantan Selatan.. Data Kependudukan. Accessed 20 Oktober 2016

[2] S.S Brahmana, Y Summarriani, dan F Ahmad, Kualitas Air dan Eutrofikasi Waduk Riam Kanan di Kaliman Selatan. Prosiding Seminar Nasional Limnologi V. Puslitbang Sumber Daya Air, Bandung, 2010

[3] S. Wantasen, Sudarmadji, dan Suprayogi. S, "Dampak Penggunaan Lahan Daerah Tangkapan Dan Pemanfaatan Perairan Danau Pada Eutrofikasi Dan Keberlanjutan Danau Tondano", Prosiding Seminar Nasional Limnologi VI, 2012.

[4] T.C Daniel, A.N Sharpley, dan J.L. Lemunyon. Agricultural Phosporus and Eutrophication: A Symposium Overview. J. Environ. Qual, 1998, 27:251-257

[5] H. Effendi, Telaah kualitas air: Bagi Pengelolaan Sumber Daya Dan Lingkungan Perairan, Kanisius, Jakarta, 2003.

[6] K.G Sellner, G. J Doucette, dan G. J Kirkpatrick, Harmful Algal Blooms; Causes, Impacts, and Detection, Journal of Industrial Microbiology and Biotechnology Volume 30, Issue7, 2003, pp 383-406.

[7] M. Allen, J. Brainard, J. Clark, dan F. Moser, Remote Sensing Harmful Algal Bloom Workshop: Chesapeake and Coastal Bays Region. Maryland Sea Grant Publication, Maryland, 2014

[8] A.N Saputra, P Danoedoro, dan M. Kamal, Prosiding Simposium Sains Geoinformasi V, Fakultas Geografi, Universitas Gadjah Mada, Yogyakarta, 2017

[9] R.E. Carlson, A Trophic State Index for Lakes. Minneapolis: Limnology Research Center, University of Minnesota. 1977

[10] OECD, Eutrophication of Waters: Monitoring, Assesment, and Control. Organization for Economic and Co-operative Development, Paris, Perancis, 1982

[11] R.G. Wetzel, Limnology: lake and river ecosystems, Gulf Professional Publishing, 2001

[12] Badan Pusat Statistik Kabupaten Banjar, Kabupaten Banjar Dalam Angka, Kabupaten Banjar, 2008

[13] W.E Irianto and Anong Sudarna, Karakteristik Beban Pencemaran Limbah Penduduk di Bandung dan Yogyakarta, Buletin PUSAIR, Media Kegiatan Penelitian Keairan (V) No: 21, 1996 pp 15-35 